\title{
Sistem Informasi Manajemen Laboratorium Sekolah Berbasis Web Pada SMK Muhammadiyah Kawali
}

\author{
Muhamad Ramdan $^{1}$, Agung Baitul Hikmah², Yanti Apriyani ${ }^{3}$ \\ 1,2,3 Universitas Bina Sarana Informatika \\ 1'ramdhanmuhh@gmail.com , ${ }^{2}$ agung.abl@bsi.ac.id, ${ }^{3}$ yanti.ynp@bsi.ac.id
}

\begin{abstract}
School laboratories, especially in vocational schools, are very important supporting facilities for the sustainability of education. In this laboratory students do practical learning that significantly makes students better understand the material. School laboratory management activities at SMK Muhammadiyah Kawali are all forms of recording of goods and activities that occur in the laboratory. Given the importance of laboratory functions, good laboratory management is an absolute necessity. This allows schools to more easily get real data on the state of goods and activities in the laboratory. This study aimed to produce a web-based laboratory management information system, because compared to the papper-based method, laboratory management activities using a web-based information system were considered more efficient to implement, because with the web all forms of recording could be easily done and if data is needed, all parties who had the authorization can easily get the data. The method was used waterfall method where this method provided a sequential software life-flow approach that started from analysis, design, implementation, testing and maintenance. Based on this research, it was concluded that the existence of a web-based management information system was expected to make the activities of laboratory management in SMK Muhammadiyah Kawali became better.
\end{abstract}

Keywords: Management Information Systems, School Laboratories, Waterfall Method

Abstrak: Laboratorium sekolah khususnya sekolah kejuruan merupakan sarana penunjang yang sangat penting bagi keberlangsungan pendidikan. Di laboratorium ini siswa melakukan pembelajaran secara praktik yang secara signifikan membuat siswa menjadi lebih memahami materi. Aktifitas manajemen laboratorium sekolah di SMK Muhammadiyah Kawali adalah segala bentuk pencatatan barang maupun aktifitas yang terjadi di laboratorium. Mengingat pentingnya fungsi laboratorium, maka manajemen laboratorium yang baik merupakan kebutuhan yang mutlak. Hal ini memungkinkan sekolah untuk dapat lebih mudah mendapatkan data real dari keadaan barang dan aktifitas di laboratorium. Penelitian ini bertujuan untuk menghasilkan sebuah sistem informasi manajemen laboratorium berbasis web, karena dibandingkan dengan basis kertas, aktifitas manajemen laboratorium menggunakan sistem informasi berbasis web dinilai lebih efisien untuk diterapkan, karena dengan web segala bentuk pencatatan bisa dengan mudah dilakukan dan apabila data diperlukan, semua pihak yang memiliki otorisasi bisa dengan mudah mendapatkan data tersebut. Metode yang digunakan dalam perancangan sistem informasi laboratorium Sekolah ini menggunakan metode waterfall dimana metode ini menggunakan pendekatan alur hidup perangkat lunak yang berurutan dimulai dari tahapan analisa, desain, implementasi, pengetesan dan perawatan. Berdasarkan penelitian ini, dihasilkan kesimpulan bahwa dengan adanya sistem informasi manajemen berbasis web diharapkan bisa menjadikan aktifitas manajemen laboratorium di SMK Muhammadiyah Kawali menjadi lebih baik.

Kata kunci: Sistem Informasi Manajemen, Laboratorium sekolah, Metode Waterfall

This is an open access article distributed under the Creative Commons Attribution License, which permits unrestricted use, distribution, and reproduction in any medium, provided the original work is properly cited. (02019 by author and IJSE-Indonesian Journal on Software Engineering. 


\section{A. PENDAHULUAN}

Pembelajaran praktik mempunyai tujuan agar peserta didik mampu menguasai materi pelajaran dengan lebih baik. Dalam pembelajaran praktik khususnya pada mata pelajaran C2 dan C3 di Sekolah Menengah Kejuruan (SMK) diperlukan sebuah ruangan yang bernama laboratorium.

Menurut Peraturan Menteri Pendayagunaan Aparatur Negara dan Reformasi Birokrasi Republik Indonesia No. 3 tahun 2010 dan peraturan bersama Menteri Pendidikan Nasional dan Badan Kepegawaian Negara No. 2 tahun 2010, menyatakan bahwa "Laboratorium pendidikan yang selanjutnya disebut laboratorium adalah unit penunjang akademik pada lembaga pendidikan, berupa ruangan tertutup atau terbuka, bersifat permanen atau bergerak, dikelola secara sistematis untuk kegiatan pengujian, kalibrasi, dan/atau produksi dalam skala terbatas, dengan menggunakan peralatan dan bahan berdasarkan metode keilmuan tertentu, dalam rangka pelaksanaan pendidikan, penelitian, dan/atau pengabdian kepada masyarakat."

(Batlajery, 2016) mengemukakan bahwa manajemen merupakan sebuah ilmu, proses dan seni dimana terdiri dari perencanaan, pengorganisasian, pergerakan serta upaya pengendalian yang dilakukan untuk mencapai sebuah sasaran yang sebelumnya telah ditentukan melalui pemanfaatan sumber daya.

Website sendiri menurut (Romney dan Steinbart, 2015) adalah "Sebuah software yang berfungsi untuk menampilkan dokumen - dokumen pada suatu web hingga membuat pengguna dapat mengakses internet melalui software yang terkoneksi dengan internet."

Permasalahan pada manajemen laboratorium di SMK Muhammadiyah Kawali adalah tidak optimalnya informasi yang bisa diberikan karena masih menggunakan kertas sebagai media pencatatannya, juga rentannya kerusakan data yang diakibatkan oleh kelalaian dari pihak pengelola sendiri. Dengan dikembangkannya sistem informasi berbasis web diharapkan dapat mempermudah pihak-pihak terkait untuk mengetahui informasi yang berkaitan dengan manajemen laboratorium di SMK Muhammadiyah Kawali. Melalui sistem informasi berbasis web ini, pihak sekolah tidak perlu menyediakan banyak waktu untuk mengidentifikasi informasi yang diperlukan. Untuk itu, keberadaan sistem informasi berbasis web ini diperlukan karena selama ini, informasi manajemen laboratorium di SMK Muhammadiyah Kawali belum dapat dimanfaatkan secara lebih optimal oleh pihak terkait.

\section{B. TINJAUAN PUSTAKA}

\section{HTML (Hyper Text Markup Language)}

HTML merupakan salah satu bahasa pemrograman yang sering digunakan pada dokumen web sebagai media pertukaran dokumen web. Struktur utama dokumen HTML dimulai dari tag pembuka dan diakhiri dengan tag penutup. (Hidayat, Hartono and Sukiman, 2017).

\section{PHP (Hypertext Preprocessor)}

PHP merupakan sebuah bahasa pemrograman interpreter dimana adanya sebuah pemerosesan kode baris menjadi kode mesin sehingga kode baris tersebut dapat diterjemahan dan dapat dijalankan oleh perangkat komputer

PHP disebut juga sebagai salah satu pemrograman Server Side Programming, dimana seluruh prosesnya dijalankan pada server dan tidak dijalankan pada client. PHP juga merupakan bahasa pemograman yang bersipat Open Source yang artinya bahasa yang digunakan dengan hak cipta terbuka dan bebas digunakan oleh pengguna selain itu pengguna juga dapat mengembangkan kode maupun fungsi PHP sesuai dengan kebutuhan penggunanya. (Hidayat, Hartono and Sukiman, 2017) .

\section{CSS (Cascading Style Sheet)}

CSS merupakan salah satu bahasa pemrograman yang bertujuan membangun tampilan web lebih terstruktur sehingga tampilan web tersebut lebih menarik, selain itu CSS memiliki arti menata sebuah halaman bertingkat, yang artinya CSS memiliki format elemen induk dan format elemen anak dimana format elemen anak tersebut akan secara otomatis mengikuti format 
elemen induknya ketika elemen format induknya berubah. (Hidayat, Hartono and Sukiman, 2017).

\section{Codeigniter}

Yang dimaksud dengan Codeigniter merupakan salah satu framework yang dapat diguanakan untuk membangun aplikasi berbasis web yang disusun dengan menggunakan bahasa PHP. Di dalam Codeigniter terdapat beberapa macam class yang berbentuk library dan helper. (Suharsana, Wirawan and S., 2016).

Codeigniter sendiri menggunakan metode MVC, MVC merupakan akronim dari Model, View dan Controller. Model merupakan sebuah logika bisnis dan inti dari sebuah aplikasi. View merupakan sebuah tampilan user interface dari komponen controller yang merupakan tampilan muka untuk dapat merespon sebuah event dari pengguna. Sementara komponen controller merupakan implementasi dari flow yang dapat mengontrol view dan model. (Simanjuntak, Pastima \& Kasnady, 2016).

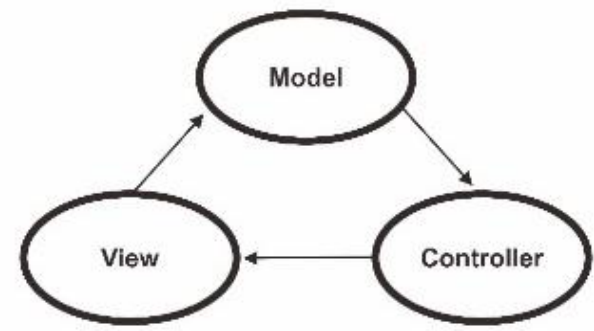

Gambar 1. Model MVC

Sumber: (Simanjuntak, Pastima \& Kasnady, 2016).

\section{Bootstrap}

Dalam dunia web programming, selain codeigniter, kita juga mengenal sebuah framework bernama bootstrap, dimana yang dimaksud dengan bootstrap adalah paket aplikasi yang siap pakai yang dapat digunakan untuk membuat design tampilan halaman front-end pada sebuah website. Dapat dikatakan pula bahwa bootstrap merupakan sebuah template desain web yang memiliki banyak fitur. (Christian, Hesinto and Agustina, 2018), sedangkan menurut (Rosid and Jakaria, 2016), yang dimaksud bootstrap adalah Framework yang kuat menyediakan set kelas CSS dan fungsi JavaScript untuk memudahkan proses membangun interface halaman web. Mengaktifkan fitur desain responsif dukungan untuk menampilkan desktop maupun mobile.

Bisa disimpulkan, bahwa pembuatan website khususnya front-end dengan menggunakan framework bootstrap bisa lebih cepat karena bootstrap memiliki library yang berisi set kelas CSS dan fungsi Javascript yang bisa dengan mudah digunakan oleh programmer.

\section{Javascript}

Menurut (B, Indra Yatini, 2014) JavaScript merupakan bahasa pemograman yang memiliki bahasa scripting kecil, ringan, dan berorientasi objek yang disematkan dalam kode HTML di proses di sisi client. JavaScript pada umumnya sering digunakan oleh programmer dalam pembuatan sebuah website karena JavaScript mempunyai kemampuan tambahan terhadap HTML lebih interaktif dan eksekusi perintah langsung di sisi browser. JavaScript juga cepat tanggap dalam merespon sebuah perintah pengguna dengan cepat dan dapat menjadikan halaman website menjadi lebih responsif

\section{Database}

Menurut (Swara and Pebriadi, 2016), basis data/database merupakan sekumpulan table, yang memiliki hubungan yang saling berkaitan dengan penyimpanan data. Salah satu jenis basis data adalah MySQL, dimana menurut (Hidayat, Hartono and Sukiman, 2017), 


\section{MYSQL}

MySQL adalah "suatu perangkat lunak database relasi DBMS (Relational Database Management Sistem), seperti halnya ORACLE, POSTGRESQL, MSSQL, dan sebagainya." Sedangkan SQL (Structure Query Language), dapat diartikan sebagai sebuah kode atau perintah-perintah tertentu dengan kata lain $S Q L$ adalah bahasa pemrograman yang digunakan untuk mengelola database. dari pengertian diatas dapat diambil kesimpulan SQL adalah bahasa atau perintah, sedangkan MySQL adalah software atau perangkat lunak yang menggunakan kode atau perintah

\section{METODE PENELITIAN}

Metode penelitian yang digunakan penulis diantaranya sebagai berikut:

\section{Metode Pengembangan Perangkat Lunak}

Metode yang digunakan pada pengembangan perangkat lunak ini menggunakan model waterfall. Metode ini memiliki tahapan-tahapan sebagai berikut:

1. Requirements analysis and definition

Tahapan ini, pengguna mendefinisikan secara rinci kebutuhan sebuah sistem, kendala, serta tujuan dari sebuah permasalahan yang berfungsi sebagai spesifikasi sistem dimana data tersebut diperoleh dari hasil konsultasi dengan pengguna.

2. System and software design

Tahapan ini, pengguna melakukan perancangan sistem dengan mengalokasikan kebutuhan sistem baik itu hardware maupun software dimana perancangan software harus mengidentifikasikan sebuah penggambaran abstraksi dari sebuah sistem dasar dari software tersebut dan hubungannya dengan membentuk sebuah arsitektur sistem dengan menggambarkan sistem secara keseluruhan.

3. Implementation and unit testing

Tahapan ini, perancangan software dapat direalisasikan dengan mengimplementasikan serangkaian program atau unit program untuk dilakukan sebuah pengujian melalui tahapan verifikasi dimana pengujian setiap unit dapat memenuhi spesifikasi yang diinginkan pengguna.

4. Integration and system testing

Tahapan ini, program digabung dan diuji secara keseluruhan menjadi sebuah sistem yang lengkap dengan tujuan untuk memastikan sesuai atau tidaknya dengan kebutuhan software. Setelah proses pengujian, software dapat dikirimkan ke pengguna untuk digunakan.

5. Operation and maintenance

Tahapan ini, sistem digunakan secara real dan tahapan ini merupakan tahapan yang sangat panjang dimana perbaikan sistem mencari kesalahan yang tidak ditemukan pada tahapan sebelumnya, melakukan peningkatan dalam layanan maupun penerapan dari unit sistem sebagai sebuah kebutuhan baru untuk pengguna.

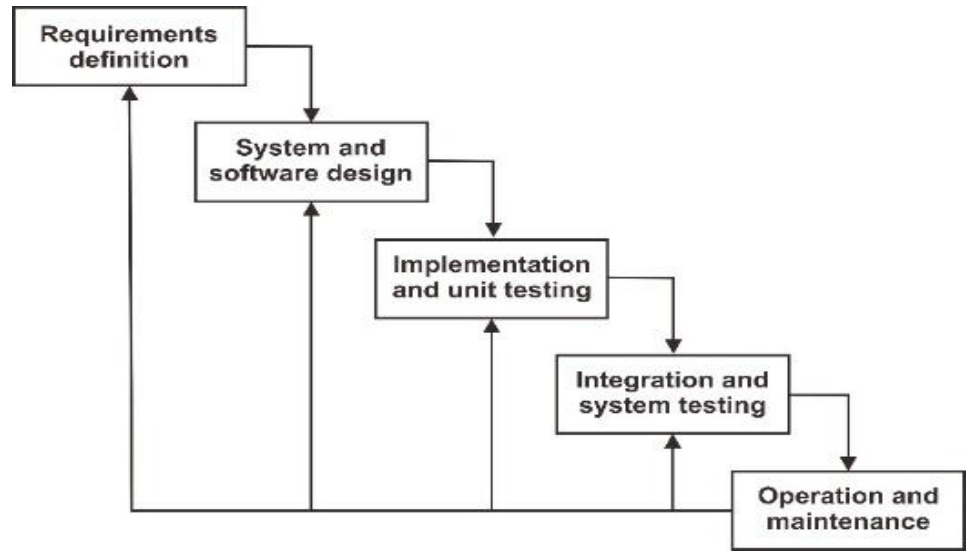

Sumber: (Sasmito, 2017)

Gambar 2. Model Waterfall 


\section{Teknik Pengumpulan Data}

Teknik pengumpulan data yang digunakan oleh penulis dalam melakukan pengumpulan data adalah:

1. Observasi

Penulis melakukan pengamatan secara langsung pada kegiatan yang ada keterkaitannya dengan permasalahan yang diambil. Semua hasil pengamatan langsung penulis catat sehingga dari kegiatan pengamatan ini dapat diketahui masalah atau kendala yang terjadi serta proses yang berlangsung dalam pencatatan inventaris barang, pencatatan peminjaman barang, jadwal pakai laboratorium serta pembuatan lembar kerja bagi laboran.

2. Wawancara

Dalam penulisan jurnal ini, untuk memperoleh informasi secara detail dan lengkap penulis melakukan metode tanya jawab dengan kepala sekolah, wakil kepala sekolah bidang sarana dan prasarana, wakil kepala sekolah bidang kurikulum, kepala laboratorium serta dengan beberapa laboran.

3. Studi Pustaka

Melalui studi pustaka, penulis mengumpulkan data-data pendukung untuk menyusun jurnal ini. Dengan mengambil referensi sebagai pendukung data yang telah didapat dari jurnal ilmiah ataupun literatur-literatur yang berkaitan dengan penulisan jurnal ini, serta mesin pencari di internet yang mengacu pada pembahasan yang berkaitan dengan objek penelitian.

\section{HASIL DAN PEMBAHASAN}

\section{Tahapan Requirements Analysis And Definition}

\section{Skenario Kebutuhan Pengguna}

a. Admin

Admin memliki akses sebagai berikut:

1) Login

Admin harus melakukan login sesuai dengan username dan password yang telah dibuat, jika validasi bernilai benar maka login berhasil dilakukan, dan Admin dapat mengakses sistem informasi manajemen laboratorium sekolah.

2) Mengelola Admin

Admin dapat menambah, menghapus dan dapat mengedit data admin.

b. Laboran

Admin memliki akses sebagai berikut:

a) Login

Laboran harus melakukan login sesuai dengan username dan password yang telah dibuat, jika validasi bernilai benar maka login berhasil dilakukan, dan laboran dapat mengakses sistem informasi manajemen laboratorium sekolah.

3) Mengelola Data Barang Tidak Habis Pakai (BTHP)

Laboran dapat menambah, menghapus dan dapat mengedit data barang tidak habis pakai (BTHP).

4) Mengelola Data Barang Habis Pakai (BHP)

Laboran dapat menambah, menghapus dan dapat mengedit data barang habis pakai (BHP).

5) Mengelola Data Peminjam

Laboran dapat menambah, menghapus dan dapat mengedit data peminjam.

6) Mengelola Data Peminjaman

Laboran dapat menambah, menghapus dan dapat mengedit data peminjaman.

7) Mengelola Data Jobsheet

Laboran dapat menambah, menghapus dan dapat mengedit data jobsheet.

c. Visitor

Visitor yang terdiri dari kepala sekolah dan wakil kepala sekolah bidang sarana dan prasarana memliki akses sebagai berikut: 
IJSE - Indonesian Journal on Software Engineering, Vol.5, No. 2, Desember 2019, 80-89 pISSN: 2461-0690 I elSSN: 2714-9935

a) Login

Visitor harus melakukan login sesuai dengan username dan password yang telah dibuat, jika validasi bernilai benar maka login berhasil dilakukan, dan laboran dapat mengakses sistem informasi manajemen laboratorium sekolah.

b) Melihat Data Barang

Visitor dapat melihat data barang per jurusan baik barang habis pakai (BHP) ataupun barang tidak habis pakai (BTHP)

\section{Skenario Kebutuhan Sistem}

a. Sistem memproses login dari pengguna dengan memastikan username dan password dari pengguna benar atau menolak login ketika username dan password salah.

b. Sistem dapat melakukan penyimpanan data yang dikelola pengguna.

c. Sistem dapat memperbaharui data yang dikelola sesuai instruksi pengguna.

d. Sistem dapat menghapus data yang dikelola sesuai instruksi pengguna.

e. Sistem dapat membuat laporan data yang dikelola pengguna.

f. Sistem dapat memproses logout setelah pengguna selesai menggunakan program.

\section{Tahapan System and Software Design}

\section{a. Struktur Navigasi}

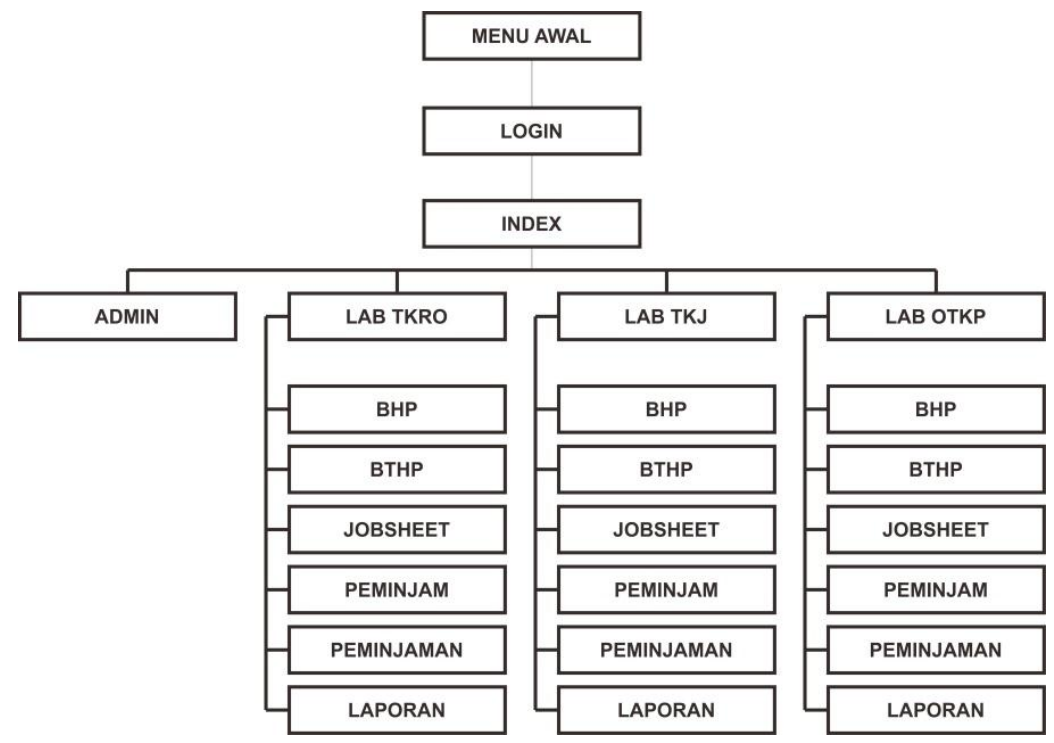

4. Spesifikasi Hardware

Gambar 3. Struktur Navigasi Utama

a. Server

1). $\mathrm{CPU}$
a) Processor Pentium $\AA$ Core 2 Duo
b) RAM 2 GB
c) Hardisk $200 \mathrm{~GB}$

2). Mouse

3). Keyboard

4). Monitor dengan resolusi direkomendasikan $1366 \times 768$ pixel

5). Koneksi internet dengan kecepatan minimal $2 \mathrm{Mbps}$

b. Client
1). $\mathrm{CPU}$
a) Processor Pentium ${ }^{\circledR}$ Core 2 Duo
b) RAM 2 GB
c) Hardisk $200 \mathrm{~GB}$

2). Mouse

3). Keyboard 
4). Monitor dengan resolusi direkomendasikan $1366 \times 768$ pixel

5). Koneksi internet dengan kecepatan minimal $2 \mathrm{Mbps}$

\section{Spesifikasi Software}

a. Server

1) Sistem operasi berbasis GUI (Graphical User Interface) minimal Windows Xp

2) Aplikasi bundle web server seperti Xampp atau WampServer

b. Client

1) Aplikasi web browser seperti Google Chrome, Mozilla Firefox, Internet Explorer

\section{Implementation and Unit Testing}

a. Implementation

\section{Selamat Datang}
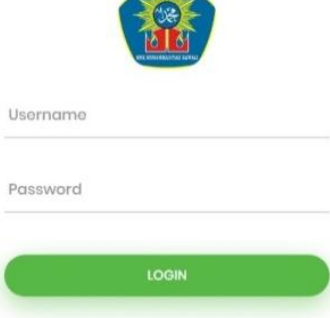

Gambar 4. Design Antar Muka Halaman Login

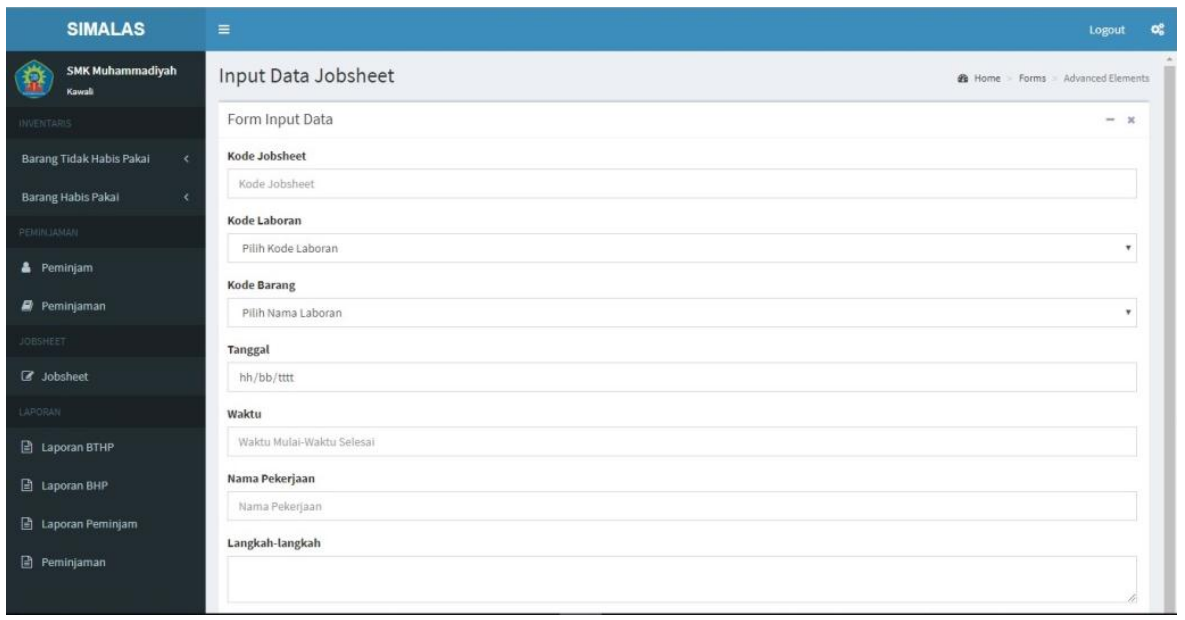

Gambar 5. Design Antar Muka Halaman Jobsheet

b. Unit Testing

Tabel 1. Hasil Pengujian Black Box Testing Halaman Login

\begin{tabular}{|c|c|c|c|c|c|}
\hline No. & $\begin{array}{c}\text { Skenario } \\
\text { pengujian }\end{array}$ & Test case & $\begin{array}{c}\text { Hasil yang } \\
\text { diharapkan }\end{array}$ & $\begin{array}{c}\text { Hasil } \\
\text { pengujian }\end{array}$ & Kesimpulan \\
\hline
\end{tabular}




\begin{tabular}{|c|c|c|c|c|c|}
\hline 1. & $\begin{array}{l}\text { Username dan } \\
\text { password tidak } \\
\text { diisi kemudian } \\
\text { klik tombol } \\
\text { login }\end{array}$ & $\begin{array}{l}\text { Username } \\
\text { (kosong) } \\
\text { Password: } \\
\text { (kosong) }\end{array}$ & $\begin{array}{lr}\text { Sistem } & \text { akan } \\
\text { menolak akses } \\
\text { user dan } \\
\text { mengembalikan } \\
\text { ke halaman login }\end{array}$ & $\begin{array}{c}\text { Sesuai } \\
\text { harapan }\end{array}$ & Valid \\
\hline 2. & $\begin{array}{l}\text { Mengetikkan } \\
\text { username dan } \\
\text { password tidak } \\
\text { diisi atau } \\
\text { kosong } \\
\text { kemudian klik } \\
\text { tombol login }\end{array}$ & $\begin{array}{l}\text { Username: apid } \\
\text { Password: } \\
\text { (kosong) }\end{array}$ & $\begin{array}{lr}\text { Sistem akan } & \text { menolak akses } \\
\text { user dan } & \text { mengembalikan } \\
\text { ke halaman login }\end{array}$ & $\begin{array}{c}\text { Sesuai } \\
\text { harapan }\end{array}$ & Valid \\
\hline 3. & $\begin{array}{l}\text { Username } \\
\text { tidak diisi } \\
\text { (kosong) dan } \\
\text { password diisi } \\
\text { kemudian klik } \\
\text { tombol login }\end{array}$ & $\begin{array}{l}\text { Username: } \\
\text { (kosong) } \\
\text { Password: } \\
\text { hapidin }\end{array}$ & $\begin{array}{lr}\text { Sistem } & \text { akan } \\
\text { menolak akses } \\
\text { user dan } \\
\text { mengembalikan } \\
\text { ke halaman login }\end{array}$ & $\begin{array}{c}\text { Sesuai } \\
\text { harapan }\end{array}$ & Valid \\
\hline 4. & $\begin{array}{l}\text { Mengetikkan } \\
\text { salah satu } \\
\text { kondisi salah } \\
\text { pada } \\
\text { username atau } \\
\text { password } \\
\text { kemudian klik } \\
\text { tombol login }\end{array}$ & $\begin{array}{l}\text { Username: apid } \\
\text { (benar) } \\
\text { Password: } \\
\text { haapidin (salah) }\end{array}$ & $\begin{array}{lr}\text { Sistem } & \text { akan } \\
\text { menolak akses } \\
\text { user dan } \\
\text { mengembalikan } \\
\text { ke halaman login }\end{array}$ & $\begin{array}{c}\text { Sesuai } \\
\text { harapan }\end{array}$ & Valid \\
\hline 5. & $\begin{array}{l}\text { Mengetikkan } \\
\text { username dan } \\
\text { password } \\
\text { dengan data } \\
\text { yang benar } \\
\text { kemudian klik } \\
\text { tombol login }\end{array}$ & $\begin{array}{l}\text { Username: apid } \\
\text { (benar) } \\
\text { Password: } \\
\text { hapidin (benar) }\end{array}$ & $\begin{array}{l}\text { Sistem } \\
\text { menerima akses } \\
\text { login dan } \\
\text { kemudian } \\
\text { langsung } \\
\text { menampilkan } \\
\text { menu sesuai } \\
\text { jabatan. }\end{array}$ & $\begin{array}{c}\text { Sesuai } \\
\text { harapan }\end{array}$ & Valid \\
\hline
\end{tabular}

Tabel 2. Hasil Pengujian Black Box Testing Halaman Jobsheet

\begin{tabular}{|c|l|l|l|c|c|}
\hline No. & \multicolumn{1}{|c|}{$\begin{array}{c}\text { Skenario } \\
\text { pengujian }\end{array}$} & \multicolumn{1}{|c|}{ Test case } & $\begin{array}{l}\text { Hasil yang } \\
\text { diharapkan }\end{array}$ & $\begin{array}{c}\text { Hasil } \\
\text { pengujian }\end{array}$ & Kesimpulan \\
\hline 1. & $\begin{array}{l}\text { Kode } \\
\text { Jobsheet } \\
\text { tidak diisi }\end{array}$ & $\begin{array}{l}\text { kode_jobsheet: } \\
\text { (kosong) }\end{array}$ & $\begin{array}{l}\text { Sistem akan } \\
\text { menolak akses } \\
\text { dan terdapat } \\
\text { tulisan "Harap } \\
\text { isi bidang ini!" }\end{array}$ & $\begin{array}{c}\text { Sesuai } \\
\text { harapan }\end{array}$ & Valid \\
\hline 2. & $\begin{array}{l}\text { Kode } \\
\text { Laboran } \\
\text { dibiarkan } \\
\text { dalam kondisi } \\
\text { default }\end{array}$ & $\begin{array}{l}\text { kode_laboran: } \\
\text { (Pilih } \\
\text { Laboran) Kode }\end{array}$ & $\begin{array}{l}\text { Sistem akan } \\
\text { menolak akses } \\
\text { dan terdapat } \\
\text { tulisan "Harap } \\
\text { pilih bidang ini!" }\end{array}$ & $\begin{array}{c}\text { Sesuai } \\
\text { harapan }\end{array}$ & Valid \\
\hline
\end{tabular}




\begin{tabular}{|c|l|l|l|c|c|}
\hline 4. & $\begin{array}{l}\text { Nama } \\
\text { Laboran } \\
\text { dibiarkan } \\
\text { dalam kondisi } \\
\text { default }\end{array}$ & $\begin{array}{l}\text { nama_laboran: } \\
\text { (Pilih Nama } \\
\text { Laboran) }\end{array}$ & $\begin{array}{l}\text { Sistem akan } \\
\text { menolak akses } \\
\text { dan terdapat } \\
\text { tulisan "Harap } \\
\text { pilih bidang ini!" }\end{array}$ & $\begin{array}{c}\text { Sesuai } \\
\text { harapan }\end{array}$ & Valid \\
\hline 5. & $\begin{array}{l}\text { Tanggal tidak } \\
\text { diisi }\end{array}$ & tanggal: (hh/bb/ttt) & $\begin{array}{l}\text { Sistem akan } \\
\text { menolak akses } \\
\text { dan terdapat } \\
\text { tulisan "Harap } \\
\text { isi bidang ini!" }\end{array}$ & $\begin{array}{c}\text { Sesuai } \\
\text { harapan }\end{array}$ & Valid \\
\hline 6. & $\begin{array}{l}\text { Waktu tidak } \\
\text { diisi }\end{array}$ & waktu (kosong) & $\begin{array}{l}\text { Sistem akan } \\
\text { menolak akses } \\
\text { dan terdapat } \\
\text { tulisan "Harap } \\
\text { isi bidang ini!" }\end{array}$ & $\begin{array}{c}\text { Sesuai } \\
\text { harapan }\end{array}$ & Valid \\
\hline 7. & $\begin{array}{l}\text { Nama } \\
\text { Pekerjaan } \\
\text { tidak diisi }\end{array}$ & pekerjaan (kosong) & $\begin{array}{l}\text { Sistem akan } \\
\text { menolak akses } \\
\text { dan terdapat } \\
\text { tulisan "Harap } \\
\text { isi bidang ini!" }\end{array}$ & $\begin{array}{c}\text { Sesuai } \\
\text { harapan }\end{array}$ & Valid \\
\hline 8. & $\begin{array}{l}\text { Langkah- } \\
\text { langkah }\end{array}$ & $\begin{array}{l}\text { Sistem akan } \\
\text { menolak akses } \\
\text { dan terdapat } \\
\text { tulisan "Harap } \\
\text { isi bidang ini!" }\end{array}$ & Sesuai \\
harapan & Valid \\
\hline
\end{tabular}

\section{E. KESIMPULAN}

Berdasarkan hasil perancangan sistem informasi manajemen laboratorium sekolah berbasis web pada SMK Muhammadiyah Kawali ini memiliki kesimpulan, yaitu:

1. Sistem informasi manajemen laboratorium sekolah berbasis web ini memberikan solusi bagi pengguna untuk mengelola dan mendapatkan informasi yang lebih optimal mengenai manajemen laboratorium sekolah di SMK Muhammadiyah Kawali

2. Sistem informasi manajemen laboratorium sekolah berbasis web ini bisa menggantikan sistem yang sudah berjalan sebelumnya yang mana sebelumnya masih menggunakan kertas sebagai media pencatatannya.

3. Resiko kehilangan data seperti pada sistem sebelumnya bisa diminimalisir.

\section{REFERENSI}

B, Indra Yatini, I. Y. (2014) 'Aplikasi Pengolahan Citra Berbasis Web Menggunakan Javascript dan Jquery', Tugas Akhir, 3(3), pp. 1-8.

Batlajery, S. (2016) 'Penerapan Fungsi-Fungsi Manajemen Pada Aparatur Pemerintahan Kampung Tambat Kabupaten Merauke', Jurnal IImu Ekonomi dan Sosial, VII(2), pp. 135-155.

Christian, A., Hesinto, S. and Agustina, A. (2018) 'Rancang Bangun Website Sekolah Dengan Menggunakan Framework Bootstrap ( Studi Kasus SMP Negeri 6 Prabumulih )', Jurnal Sisfokom (Sistem Informasi dan Komputer), 7(1), p. 22. doi: 10.32736/sisfokom.v7i1.278.

Hidayat, H., Hartono and Sukiman (2017) 'Pengembangan Learning Management System (LMS) untuk Bahasa Pemrograman PHP', Jurnal IImiah Core IT: Community Research Information Technology, 5(1), pp. 20-29.

Romney dan Steinbart (2015) 'Sistem Informasi Penjadwalan Dokter Berbassis Web Dengan Menggunakan Framework Codeigniter', Teknoinfo, 11(2), pp. 30-37.

Rosid, M. A. and Jakaria, R. B. (2016) 'Implementasi Framework Twitter Bootstrap Dalam Perancangan Aplikasi Penerimaan Mahasiswa Baru Berbasis Web', Kinetik, 1(3), p. 129. doi: $10.22219 /$ kinetik.v1i3.121.

Sasmito, G. W. (2017) 'Penerapan Metode Waterfall Pada Desain Sistem Informasi Geografis 
Industri Kabupaten Tegal', Jurnal Pengembangan IT, 2(1), pp. 6-12.

Simanjuntak, Pastima \& Kasnady, A. (2016) 'Analisis Model View Controller (Mvc) Pada Bahasa Php', Jurnal ISD, 2(2), pp. 56-66.

Suharsana, I. K., Wirawan, I. W. W. and S., N. L. A. K. Y. (2016) 'Implementasi Model View Controller Dengan Framework Codeigniter Pada E-Commerce Penjualan Kerajinan Bali', 11.

Swara, G. Y. and Pebriadi, Y. (2016) 'Rekayasa perangkat lunak pemesanan tiket bioskop berbasis web', Jurnal TEKNOIF, 4(2), pp. 27-39. 